\title{
Retrofitting potential of an existing tourist lodge for improved environmental performance: an investigation
}

\author{
S. Bardhan ${ }^{1}$, B. Ghosh ${ }^{2}$, S. Hazra ${ }^{3}$ \& M. Chatterjee ${ }^{1}$ \\ ${ }^{1}$ Department of Architecture, Jadavpur University, India \\ ${ }^{2}$ School of Energy Studies, Jadavpur University, India \\ ${ }^{3}$ School of Oceanographic Studies, Jadavpur University, India
}

\begin{abstract}
Tourism industry involves a wide range of constructional activities in terms of development of infrastructure and lodging facilities in tourist destinations. Hotels, resorts, lodges etc. are known to be resource intensive, especially during their operation-cum-maintenance period. This is critical, when seen in the context of sensitive ecological belts, as is common for nature based tourism. Such a tourist lodge not only replaces a certain amount of local flora and fauna in its own site and immediate surroundings, but also continues to load the ecosystem by using substantial energy and other resources for its day to day functioning. Since these structures are 24-hour operational, the cumulative effect of this may eventually exceed the carrying capacity of the eco-system supporting it. This paper attempts to present a study that examines the possibilities of ecointervention by retrofitting one such existing tourist lodge with active and passive resource-efficient measures with an intention to find the theoretical improvement in its environmental performance. The building in question is a medium capacity tourist lodge located in the ecologically fragile coastal belt of the Indian Sundarbans overlooking Bay of Bengal in the state of West Bengal, India. The process involves mapping of the current consumption/generation pattern of the structure in terms of energy and water and compares these footprints with the post-retrofit situation of the same building. Since energy consumed by these structures depends on the conventional systems of electrical grid and the stand-by Diesel Generator, Carbon emission becomes a critical criterion in the measurement. The study also covers the indirect benefits of these retrofits on local plant species. The final results of this analytical study were
\end{abstract}


found to be largely positive pointing towards an over-all reduced carbon emission and environmental impact of the tourist building.

Keywords: natural resources, eco-compatibility, building sustainability, environmental retrofit, carbon emission.

\section{Introduction}

In developing countries, tourism can be considered as a means of redistributing economic resources, mitigating the socio-economic situation at local, national and international scales and contributing to biodiversity conservation. It is important that such tourism is fully compatible with sustainable development goals and appropriately addresses the environmental indicators of ecosystems and biodiversity, waste disposal, water consumption, intensity of land use and physical impact, protection of the atmosphere, noise level and visual impact [1]. The Indian Sundarbans forests to the south of West Bengal in Eastern India is a complex and unique tiger inhabited mangrove eco-system and salt water swamp constituting the lower part of Gangetic delta. It is located between $21^{\circ} 31^{\prime}$ to $22^{\circ} 53^{\prime} \mathrm{N}$ latitude and $88^{\circ} 37$ to $89^{\circ} 09^{\prime} \mathrm{E}$ longitude and is about $140 \mathrm{~km}$ southeast of the Calcutta metropolis. The Sundarbans forest has been declared a World Heritage site under Natural criteria ix and $\mathrm{x}$ by UNESCO in 1987 in recognition of its rich bio-diversity and incomparable natural value. A major part of this region also supports human habitation that depends on the forests and the local resources for sustenance. Agriculture, pisciculture, aquaculture and animal husbandry are some of the main occupations of these people. Over the last decade, the population of this region has increased from 3.2 million as per the 1991 census to around 4.0-4.5 million at present. Majority of the people are living below poverty line (BPL), which is defined as an income group with a family income of not more than US\$ 130 per year or less than one US \$ per day. On another hand, the pristine beauty of the natural setting of sea, beach, forest and wildlife attracts hordes of tourists every year. Thus eco-tourism is perceived to be a very viable and environmentally sustainable employment option for the region. However, responding to the popular demand, tourism activities have already grown in an unplanned and ad-hoc manner. The tourism sector is also in serious discord with the fragile coastal ecology of the Sundarbans. Currently, these activities are proliferating at different eco-sensitive regions in an unregulated way, largely characterized by considerable consumption of natural resources and subsequent generation of waste. This leads to natural resource depletion, pollution and emissions and collectively threatens the survival of the very eco-system which sustains them. The result is disastrous in terms of environmental, social and economic health of the region and therefore, is a challenge to these three fundamental dimensions of sustainability.

In this backdrop, an assessment study of an existing tourist facility at Bakkhali, a coastal location popular for its beach tourism, was carried out to check its environmental performance. The tourist facility in question is a three storied lodge of about $387 \mathrm{Sq} \mathrm{m}(4164.12 \mathrm{sq} \mathrm{ft})$ plinth area and a capacity of 60 beds. Energy and water were considered as the major environmental indices for 
this assessment and the average annual energy consumption, referred as energy foot-print as well as the average annual water consumption, referred as water foot-print were measured on the basis of field survey results. The operational energy foot-print of the tourist lodge was found to be about $212 \mathrm{kWh} / \mathrm{Sqm} / \mathrm{year}$ while the water foot-print was found to be $14.6 \mathrm{Cum} / \mathrm{Sqm} / \mathrm{year}$. The energy expended in pumping this water in the overhead tank with a 1.5 H.P. pump was found to be an additional $13.5 \mathrm{kWh} / \mathrm{Sqm} /$ year. Hence, the total energy foot-print of the said lodge worked out to be about $225 \mathrm{kWh} / \mathrm{Sqm} /$ year. This value was again converted into an equivalent quantity of carbon emission and referred as carbon foot-print, calculated on the basis of carbon emission per unit of oil based electricity produced [2]. It was found that its average carbon foot-print was 74.01 ton $\mathrm{C}$ per year, which is very high and detrimental to the region when considered in extended spatial and temporal terms. It was, therefore, felt necessary to understand the degree of eco-intervention required to retrofit and convert this existing tourist lodge into a sustainable and eco-tourism one. The present paper discusses the result of the investigation carried out to assess the retrofit potential of this lodge with respect to energy and water resources. These retrofitting measures aimed at correcting the building in favour of eco-compatibility. In course of this investigation, it was found that the current energy sources available to the local community, in general and the tourist lodge, in particular were highly inadequate. Regular disruption in grid-power services is quite common, which prompts the locals and lodge owners to switch over to diesel generators- a sure source of air and noise pollution. The energy required for cooking/ heating water is achieved by burning either fossil fuels or woody biomass. Local transportation is also dependent on fossil fuel use. Burning of biomass and fossil fuels not only trigger emission of Green House Gases (GHG-s) and particulates but also threatens supply securities. All these collectively add stress to the bio-diversity of the sensitive mangrove forest and are also alarming in the context of global warming and climate change. Thus, finding a more efficient alternative to fossil fuels and bio-mass became imperative as ecotourism has to adhere to the Clean Development Methods as part of ecodevelopment.

\subsection{Architectural integration of the sustainability measures}

In order to qualify as sustainable tourism, the energy demand of the lodge as mentioned in the previous paragraph needed to be met from clean and renewable sources instead of fossil fuels and forest bio-mass. In Indian solar radiation condition, the availability of solar power in that region is about $800 \mathrm{~W} / \mathrm{m}^{2}$ for five hours duration i.e. $4000 \mathrm{Wh} / \mathrm{m}^{2} /$ day [3]. With this abundant solar energy, retrofitting potential of renewable energy systems like the solar Photovoltaic (PV) and solar thermal were considered to be very high and worthy of investigation, especially because it would be easy to integrate these with the existing building fabric, particularly on the building roof. The electricity production using photovoltaic route would reduce the diesel consumption and production of hot water through solar thermal route would lessen the load on the bio-mass consumption, optimize energy-efficiency and reduce the energy foot- 
print considerably. Similarly, water sustainability was considered to be achievable through water recycling measures and other available technologies. Apart from these building retrofits, landscape measures were considered to be of very high potential in terms of carbon sequestration, environmental amelioration and ecological restoration. This has been discussed in details in this paper.

\subsection{Retrofit potentials of the existing tourist facilities}

As discussed, the possible ways of adapting and integrating sustainable measures with the existing tourist structure were identified as follows:

1. Reducing energy foot-print by

a. Introduction of Renewable energy sources through solar PV panels

b. Use of solar thermal for heating water

2. Reducing water foot-print by

a. Rain Water Harvesting (RWH) to supplement the total water demand

b. Grey Water Recycling (GWR) for non-potable use

3. Carbon offsetting by appropriate landscaping and tree plantation to neutralize the $\mathrm{CO}_{2}$ emissions, to the maximum extent possible.

The following sections take up the above issues one at a time and suggest retrofitting options based on quantitative assessment of the technologies concerned. These techniques have been matched with the actual conditions and demands of the said tourist facility to address the case-specific needs and adjudge the corresponding environmental benefits achieved through the suggested retrofits.

\section{Energy}

\subsection{Retrofit potential for solar photovoltaics}

The solar photovoltaic or PV applications are closely related to the concept of sustainable architecture and eco-tourism as it generates power from the renewable source of sunshine without any noise pollution or emission. The initial investments costs can also be reduced if the PV power system is integrated within the building by replacing the existing building components. The photovoltaic generators can be installed over the tourist lodge roof in south-east façade at an inclination of $22.5^{\circ}$ in order to produce the maximum electricity. These PV generators may be designed for a nominal voltage of $24 \mathrm{~V}$. In the selected building, the open roof area is $387 \mathrm{Sqm}$ or $4164.12 \mathrm{sq} \mathrm{ft}$. The solar PV modules available in the market have generation capacity of around $10.62 \mathrm{~W} / \mathrm{sq} \mathrm{ft} / \mathrm{hr}$. The approximate electricity generation capacity covering the entire roof will then be about $220 \mathrm{kWh}(4164.12 \mathrm{sq} f t \times 10.62 \mathrm{~W} / \mathrm{sq}$ ft / hour $x 5$ $h r s)$ per day. As mentioned earlier, the annual energy demand being $225 \mathrm{kWh} / \mathrm{Sqm}$, it is around $238 \mathrm{kWh}$ per day and which is slightly higher than the solar energy harnessing potential of roof-top solar PV modules. Since the 
architectural integration of the solar PV modules can be made at a height with enough headroom from the existing roof top, the covered space so formed can also be utilized for tourism related activities and help in additional revenue generation. Further, shading from the solar PV will substantially reduce the heat gain of the building from its roof and keep the interiors cooler. Thus direct and immediate benefits through this multi-advantageous solar PV installation can act as an incentive and be compensatory to the initial investment and procurement cost. The long term environmental benefit associated with this adaptation is also multi-dimensional. Elimination of air and noise pollution will lead to better health of the local community as well as the bio-diversity. A measurable benefit was of course reduction in $\mathrm{CO}_{2}$ emission, which was to the tune of $(220 \times 0.85)$ $=187 \mathrm{KgC} /$ day or 68.25 Tons of $\mathrm{CO}_{2}$ per year and a savings of $25756 \mathrm{Lt}$. of diesel fuel per year.

However, the energy involvement in the production process of the most common type of module, which uses multi-crystalline silicon, releases $37 \mathrm{gm} /$ $\mathrm{kWh}$ of Green House Gases of $\mathrm{CO}_{2}$ equivalent to the atmosphere [2]. Therefore, the captive $\mathrm{CO}_{2}$ Emission component within the solar modules for generation of $220 \mathrm{kWh}$ will be $(220 \times 0.037)=8.14 \mathrm{KgC} /$ day. Hence, the net environmental benefits after accounting for this captive emission worked out to be 178.86 $\mathrm{KgC} /$ day or $65.28 \times 10^{3} \mathrm{KgC} /$ year. This has been shown below in Table 1 .

Table 1: $\quad \mathrm{CO}_{2}$ Offsetting from Solar 'PV' Integration.

\begin{tabular}{|c|c|c|c|}
\hline $\mathrm{A}$ & $\mathrm{B}=\mathrm{A} \times 0.85$ & $\mathrm{C}=\mathrm{A} \times 0.037$ & $\mathrm{D}=(\mathrm{B}-\mathrm{C}) \times 365$ \\
\hline $\begin{array}{c}\text { Power } \\
\text { generation } \\
\text { potential }\end{array}$ & $\begin{array}{c}\text { Reduction } \\
\text { Potential of CO } \mathbf{C}_{2} \\
\text { Emission }\end{array}$ & $\begin{array}{c}\text { Captive Emission } \\
\text { component of the } \\
\text { installed solar PVs }\end{array}$ & $\begin{array}{c}\text { Net annual } \\
\text { negation in CO } \mathbf{C}_{2} \\
\text { emission per year }\end{array}$ \\
\hline $\mathrm{kWh} /$ day & $\mathrm{KgC} /$ day & $\mathrm{KgC} /$ day & $\mathrm{KgC} / \mathrm{year}$ \\
\hline 220 & 187 & 8.14 & $65.28 \times 10^{3}$ \\
\hline
\end{tabular}

Thus, the net annual negation potential in $\mathrm{CO}_{2}$ emission was about $88 \%$ of the measured carbon foot-print or the annual $\mathrm{CO}_{2}$ generated by the lodge, which is 74. $01 \times 10^{3} \mathrm{KgC} /$ year, as was mentioned in the introduction. The balance $8.73 \mathrm{x}$ $10^{3} \mathrm{KgC} /$ year of $\mathrm{CO}_{2}$ needs to be further reduced through other retrofit measures.

\subsection{Retrofit potential for solar thermal}

The retrofit possibilities of Building Integrated Solar Thermal (BIST) in the existing tourist facilities were investigated for optimum ways of successful integration. The Solar Thermal (ST) products commercially available in the market with the flat plate collector system offer integration solutions either with the façade or on the roof itself. Since the building has longer axis in N-S direction with front balconies facing north, balcony integration option for this face can virtually be ruled out. Hence the possible building components that can accommodate the solar thermal collectors are either the roof and balcony parapet with high solar exposure or the south-facing building façade, which is 
advantageously the rear façade. Bulk of the hot water required is to meet the bathing water demand of tourists in any tourist facility. Studies on water use pattern shows that about $30 \%$ of the per capita water consumption accounts for bathing, which comes to about $0.3 \times 180 \mathrm{Lt}$ per capita per day (lpcd) $=54 \mathrm{lpcd}$.

Considering a total of 64 people including guests and staff, this comes to $(64 \times 54)=3456 \mathrm{Lts} /$ day. In order to find out the energy required to heat this volume of water, the following assumptions were made:

i. Since hot water requirement is mostly during the winters i.e. October to February only, the average number of days requiring heating of water has been considered to be 150 .

ii. Temperature of water in winters is $20^{\circ} \mathrm{C}$

iii. Temperature of heated water at comfort level is $26^{\circ} \mathrm{C}$

Since one Calorie of heat energy is required to raise one gm (or $1 \mathrm{cc}$ ) of water by $1^{\circ} \mathrm{C}$, to raise the temperature of $3456 \mathrm{Lt}$ of water by $(26-20)=6^{\circ} \mathrm{C},\{(3456 \mathrm{x}$ $\left.\left.10^{3}\right) \mathrm{cc} \times 6\right\}=20736 \times 10^{3}$ calories or $\left(20736 \times 10^{3} \times 1.16 \times 10^{-6}\right)=24 \mathrm{kWh}$ of energy would be required per day towards this purpose. Studies by Dias and Pooliyadda [4] have specified the TOE (tonnes of oil equivalent) of biomass, mainly firewood to be 0.38 , where, one $\mathrm{TOE}=41.84 \mathrm{GJ}$, meaning $1 \mathrm{Mt}$ of firewood will consume $(0.38 \times 41.84 \mathrm{GJ})=15.9$ GJ of energy (i.e. $\equiv 4420 \mathrm{kWh}$ for $1000 \mathrm{Kg}$ of biomass or $4.42 \mathrm{kWh} / \mathrm{Kg}$ ). For $24 \mathrm{kWh}$ of energy required, biomass consumption is about $5.4 \mathrm{Kg} /$ day. Studies specified Greenhouse gas emission to be 45 grams per kilowatt-hour of $\mathrm{CO}_{2}$ Equivalent for bio-mass based fossil fuel form of energy supply [2]. Since the energy needed for heating water is at present being met by using bio-mass, the corresponding $\mathrm{CO}_{2}$ emission for 150 days can be calculated as $(24 \times 0.045 \times 150)=162 \mathrm{KgC} /$ year for this Lodge.

Again, the total bathing water requirements were assessed vis-à-vis capacity of the solar thermals to check the technical feasibility of architectural integration in the said Lodge. The following Tables give a quantitative assessment of the Solar Thermal adaptation and the associated benefits arising from it. These benefits manifest in two forms- one, avoiding bio-mass based energy consumption along-with its subsequent $\mathrm{CO}_{2}$ emission, (as shown in the above calculations) and two, preventing bio-mass burning and thus, saving the biomass itself. This implies saving of trees, which in turn will help in fixing the atmospheric $\mathrm{CO}_{2}$. These have been tabulated below under 'Direct' and 'Indirect' environmental benefits under Tables 2 and 3 respectively.

A $2.0 \mathrm{~m} \times 2.0 \mathrm{~m}$ collector would yield $100 \mathrm{Lts}$ of hot water at $65^{\circ} \mathrm{C}$ every $3.5 \mathrm{hrs}$, i.e. effectively one day. This volume of water is equivalent to $600 \mathrm{Lt}$ of usable water. Above calculations show that 6 nos. of solar panels are sufficient to yield the required water. This means $6 \times 2 \mathrm{~m}=12 \mathrm{RM}$ (running meter) length of roof parapet can be utilized for this purpose. For façade integration, $6 \times 4 \mathrm{Sqm}=$ $24 \mathrm{Sqm}$ area can also be considered as an alternative to the parapet option. However, from maintenance and servicing points of view, the former appears more convenient and viable than the latter. The said number of collectors with the above dimensions would be easily accommodated on the roof parapet. Assessment of indirect environmental benefits involved complex calculations at multiple stages. Stage one involved finding out the annual quantity of bio-mass 
Table 2: $\quad$ DIRECT environmental benefits from solar thermal integration.

\begin{tabular}{|c|c|c|c|c|}
\hline A & B & $\mathrm{C}=\mathrm{A} / \mathrm{B}$ & $\mathrm{D}$ & $\begin{aligned} \mathrm{E}= & (\mathrm{D} \times 0.045) \\
& \times 150\end{aligned}$ \\
\hline $\begin{array}{l}\text { Hot water } \\
\text { demand } \\
\text { for the } \\
\text { tourists } @ \\
54 \text { lped } \\
\end{array}$ & $\begin{array}{l}\text { Hot water } \\
\text { output by a } \\
\text { single ST } \\
\text { collector }\end{array}$ & $\begin{array}{l}\text { Qtty. of } \\
\text { collectors } \\
\text { required }\end{array}$ & $\begin{array}{c}\text { Equivalent } \\
\text { Energy saved } \\
\text { through ST } \\
\text { from bio-mass } \\
\text { based fuel }\end{array}$ & $\begin{array}{c}\text { Direct negation } \\
\text { in } \mathrm{CO}_{2} \\
\text { Emission from } \\
\text { burning of bio } \\
\text { mass }\end{array}$ \\
\hline Lt/day & Lt/day & Nos. & $\mathrm{kWh} /$ day & $\mathrm{KgC} / \mathrm{yr}$ \\
\hline $\begin{array}{c}3456 \mathrm{Lt} \text { at } \\
26^{\circ} \mathrm{C}\end{array}$ & $\begin{array}{c}(100 \mathrm{Lt} \text { at } \\
\left.65^{\circ} \mathrm{C}\right) \equiv 600 \mathrm{Lt} \\
\text { at } 26^{\circ} \mathrm{C}\end{array}$ & $\approx 6$ & 24 & 162 \\
\hline
\end{tabular}

required for generating the energy needed for heating water. Stage two involved translating that bio-mass quantity into the actual number of trees being felled annually to supply the said amount. Stage three involved quantification of the $\mathrm{CO}_{2}$ fixed by such trees, if retained, and contribute in negating global warming effect.

\subsubsection{Finding out the annual quantity of bio-mass used}

Considering the TOE (tones of oil equivalent) of biomass, mainly firewood to be 0.38 , where one $\mathrm{TOE}=41.84 \mathrm{GJ}$, meaning $1 \mathrm{Mt}$ of firewood would consume $(0.38 \times 41.84 \mathrm{GJ})=15.9 \mathrm{GJ}$ of energy, the amount of bio-mass required to meet the previously-stated energy demand for hot-water production was found out. In other words, $15.9 \mathrm{GJ}$ or $4420 \mathrm{kWh}$ energy would be produced by $1000 \mathrm{Kg}$ of biomass or $4.42 \mathrm{kWh}$ of energy will be produced by $1 \mathrm{Kg}$ of bio-mass. This was also found to be at par with the research findings of Karmakar [5], which indicated that one $\mathrm{Kg}$ of Avicennia species - the common firewood of the region - generates about 4000 Kilocalories of heat, which is equivalent to $4.64 \mathrm{kWh}$ of energy. This formed the basis for estimating the amount of bio-mass required for heating water at the studied lodge and the bio-mass consumption was found to be about (24/4.42) or $5.4 \mathrm{Kg}$ /day. Hence the annual consumption of biomass (i.e. for 150 days of the winters) for this Lodge was calculated to be $(5.4 \times 150)=810$ $\mathrm{Kg} / \mathrm{yr}$.

\subsubsection{Finding out the equivalent number of trees}

Converting these values into actual number of trees was again an assumption based process- the rationale being effective bio-mass can be obtained from a matured tree of about $300 \mathrm{~mm}$ trunk girth and $3.5 \mathrm{~m}$ height. The volume of such tree (of height less than $3.9 \mathrm{~m}$ ) can then be calculated as $\left(\pi \mathrm{r}^{2} \mathrm{~h}\right.$ ) where $\mathrm{r}=$ Radius of the tree girth and $h=$ Height of the tree or $\left(3.14 \times 0.15^{2} \times 3.5\right)=0.247$ Cum or $\left(0.247 \times 10^{6}\right) \mathrm{cm}^{3}$. Considering density of matured mangrove wood to be $0.6 \mathrm{~g} / \mathrm{cm}^{3}$ (Karmakar [5]), the weight of each tree producing this wood would be $\left\{\left(0.247 \times 10^{6}\right) \times 0.6\right\} \mathrm{g}$ or $148.36 \mathrm{Kg}$. Therefore, the number of trees (Avicennia spp.) felled to supply the bio-mass of $810 \mathrm{Kg} / \mathrm{yr}$ to the tourist lodge worked out to be $(810 / 148.36)=5.46$ or $\approx 5$ nos per year. 


\subsubsection{Finding out the $\mathrm{CO}_{2}$ sequestered by those trees}

It has been reported by Karmakar [5] that the Carbon assimilation efficiency of Avicennia dominated mangrove eco-system is 54.75 tonnes of Carbon /hectare/year against the average value of mixed mangrove forest as 27 tonnes $\mathrm{C} /$ hectare /year. Since the Avicennia species are the most preferred firewood, the former value has been considered here, i.e. $5.47 \mathrm{KgC} / \mathrm{m}^{2} /$ year.

Considering an average Avicennia tree canopy to be $3.0 \mathrm{~m}$, each such tree will occupy $3 \times 3=9 \mathrm{~m}^{2}$ area of forested land. Therefore, each such tree will be able to fix $5.47 \times 9=49.23 \mathrm{KgC} /$ year. Hence the 5 nos. of trees will sequester a total of $(5 \times 49.23)=246.15 \mathrm{KgC} /$ year. This is tabulated below in Table 3 .

Table 3: $\quad$ INDIRECT environmental benefits from solar thermal.

\begin{tabular}{|c|c|c|c|}
\hline $\mathrm{A}$ & $\mathbf{B}$ & $\mathbf{C =} \mathbf{B} / 148.36$ & $\mathrm{D}=\mathrm{C} \times 24.3$ \\
\hline $\begin{array}{c}\text { Equivalent } \\
\text { Energy saved } \\
\text { through ST }\end{array}$ & $\begin{array}{c}\text { Bio-mass required } \\
\text { for heating the } \\
\text { same volume }\end{array}$ & $\begin{array}{c}\text { Saving of precious } \\
\text { trees }\end{array}$ & $\begin{array}{c}\mathbf{C O}_{2} \text { Sequestered } \\
\text { by the saved bio- } \\
\text { mass }\end{array}$ \\
\hline $\mathrm{kWh} / \mathrm{day}$ & $\mathrm{Kg} / \mathrm{yr}$ & $\mathrm{Nos} / \mathrm{Kr}$ & $\mathrm{KgC} / \mathrm{yr}$ \\
\hline 24 & 810 & 5 & 246.15 \\
\hline
\end{tabular}

The direct and indirect environmental benefits are summarized below in Table 4 and the cumulative benefit in terms of total $\mathrm{CO}_{2}$ offsetting achieved by retrofitting solar thermal technology for providing hot bathing water to the tourists has been enumerated.

Table 4: $\quad$ Total $\mathrm{CO}_{2}$ offsetting from solar thermal integration.

\begin{tabular}{|c|c|c|}
\hline $\mathrm{A}$ & $\mathrm{B}$ & $\mathrm{C}=\mathrm{A}+\mathrm{B}$ \\
\hline $\begin{array}{c}\text { Direct negation in } \mathbf{C O}_{2} \\
\text { Emission by solar thermal } \\
\text { As per column E of Table } \\
2]\end{array}$ & $\begin{array}{c}\mathbf{C O}_{2} \text { Sequestered by the } \\
\text { saved bio-mass } \\
\text { producing trees [As per } \\
\text { column D of Table 3 ] }\end{array}$ & Total $\mathbf{C O}_{\mathbf{2}}$ Offsetting \\
\hline $\mathrm{KgC} / \mathrm{yr}$ & $\mathrm{KgC} / \mathrm{yr}$ & $\mathrm{KgC} / \mathrm{yr}$ \\
\hline 162 & 246.15 & $\mathbf{4 0 8 . 1 5}$ \\
\hline
\end{tabular}

\section{Water}

\subsection{Retrofit potential for rain water harvesting systems}

In the context of the present study, Rain water Harvesting (RWH) was considered to be one of the most significant water retrofit tools for the following purposes:

- Efficient management and conservation of fresh water, which in many occurrences is an alarmingly depleting non-renewable resource

- Reduce the water-foot-prints of the said lodge 
- Disallow over-exploitation of ground-water in the coastal region, to prevent salt water intrusion into the ground water.

As mentioned earlier, the daily water requirement of the lodge is $12000 \mathrm{Lt}$ per day, which means 4380 Cum of total water demand per year. The annual Rain Water Harvesting (RWH) endowment of the lodge was assessed considering average annual rainfall as $1900 \mathrm{~mm}$ (Source: India Meteorological Department) and run-off coefficient for the roof as 0.8. The annual RWH Potential has been considered to be $60 \%$ of this Endowment, accounting for losses due to first flushing requirements and others. The RWH Potential would have two components - one, 'storage' for the purpose of direct use and two, 'recharge' for replenishment of ground water sources. As recommended by the State Pollution Control Board, the storage option would address $40 \%$ of the total potential while the rest would be used for recharge [6]. The calculations point to about 141.17 Cum of storage and a reservoir of 144 Cum internal volume with dimensions 6.0 $\mathrm{m} \times 6.0 \mathrm{~m} \times 4.0 \mathrm{~m}$ would cater to the storage requirement. The recharge option could be realised in many ways depending on local hydro-geological conditions and actual site layout. The most noteworthy finding is, however, that the total annual RWH endowment is only $13.4 \%$ of the total annual water demand and the annual RWH potential is a meager $8 \%$ of the same, as indicated in Table 5 .

Table 5: $\quad$ RWH Potential for the existing Lodge.

\begin{tabular}{|c|c|c|c|}
\hline $\mathrm{A}=($ Area $\times 1.9 \times 0.8)$ & $\mathrm{B}=0.6 \times \mathrm{A}$ & $\begin{array}{c}\mathrm{C}=0.4 \times \mathrm{B} \\
\text { Or }(\mathrm{B}-\mathrm{C})\end{array}$ \\
\hline $\begin{array}{c}\text { Total annual } \\
\text { RWH Endowment }\end{array}$ & $\begin{array}{c}\text { Annual RWH } \\
\text { Potential } \\
(\mathbf{6 0 \%} \% \text { of } \mathrm{A})\end{array}$ & $\begin{array}{c}\text { Storage potential } \\
\mathbf{( 4 0 \%} \text { of B) }\end{array}$ & $\begin{array}{c}\text { Recharge } \\
\text { potential } \\
(\mathbf{6 0 \%} \% \text { of B) }\end{array}$ \\
\hline Cum & Cum & Cum & Cum \\
\hline $\begin{array}{c}588.24 \\
{[13.4 \% \text { of annual }} \\
\text { water demand }]\end{array}$ & $\begin{array}{c}352.94 \\
\text { of annual water } \\
\text { demand }]\end{array}$ & $\begin{array}{c}141.17 \\
{[3.2 \% \text { of annual }} \\
\text { water demand }]\end{array}$ & 211.77 \\
\hline
\end{tabular}

This shows that in case of tourist facilities, RWH can play only a small supplementary role towards meeting its total annual water demand. This is because water is not only used lavishly by the guests, but is also wasted in copious amount. In this societal context, it is essential to ensure 'use efficiency' through water-efficient fittings and fixtures. Most of the toilets surveyed in this facility (and other lodges, too) had the conventional $13.5 \mathrm{Lt}$ flushing closets. If these were replaced by the dual flush toilet of $9 \mathrm{Lt}(3 \mathrm{Lt}+6 \mathrm{Lt})$ capacity, it would be possible to record substantial savings in water, i.e. a minimum saving of $(13.5-6.0)=7.5 \mathrm{Lt} /$ flush and average saving of $(13.5-3)=10.5 \mathrm{Lt} / \mathrm{flush}$. Considering one flush of $6.0 \mathrm{Lt}$ and four nos. flushing of $3 \mathrm{Lt}$, the volume of water saved is $(7.5+4 \times 10.5)=49.5 \mathrm{Lt}$ per capita per day.

For the studied Lodge, the annual savings worked out to be ( $49.5 \times 64 \times 365)$ $=1156320 \mathrm{Lt} /$ year or $1156.32 \mathrm{Cum} /$ year. 


\subsection{Retrofit potential for grey water recycling systems}

Urban Development Plans Formulation and Implementation (UDPFI) Guidelines in India has estimated waste water to be $80 \%$ of the water consumed [7]. It also recommends 180 lpcd (litres per capita per day) of water for tourist accommodations. Therefore, the per capita waste water generated in this lodge per day is $180 \times 0.8=144 \mathrm{Lt}$. This consists of both grey water and black water. For retrofitting purpose, the grey water is being only considered for recycling with intervention at source of generation by separating the two waste-water systems. Studies have also shown that grey water is usually $60 \%$ of the waste water while black water is the rest. This means $(0.6 \times 144)=86.4 \mathrm{Lt}$ per capita per day was the grey water generated from the lodge. This waste water can then undergo aerobic biological treatments like passing through a soil-box planter bed of specified dimension and constituents and using the treated water for irrigation, washing of paved areas etc. after necessary quality check. However, with limited availability of land area adjoining the tourist lodges, the retrofit potential with available techniques like grey water gardens/pressure leaching chambers etc. seemed to be only $10-15 \%$ maximum, as shown in column D of Table 6 below.

Table 6: Grey water recycling potential for the existing structures.

\begin{tabular}{|c|c|c|c|}
\hline $\mathrm{A}$ & $\mathrm{B}=0.8 \times \mathrm{A}$ & $\mathrm{C}=0.6 \times \mathrm{B}$ & $\mathrm{D}=0.1 \times \mathrm{C}$ \\
\hline $\begin{array}{c}\text { Annual } \\
\text { water } \\
\text { consumption }\end{array}$ & $\begin{array}{c}\text { Annual waste } \\
\text { water generated }\end{array}$ & $\begin{array}{c}\text { Annual Grey } \\
\text { water generation }\end{array}$ & $\begin{array}{c}\text { Volume of treated } \\
\text { water through } \\
\text { retrofitting }\end{array}$ \\
\hline $\mathrm{Cum}$ & $\mathrm{Cum}$ & $\mathrm{Cum}$ & $\mathrm{Cum}$ \\
\hline 4380 & 3504 & 2102.4 & 210.2 \\
\hline
\end{tabular}

\section{Landscape elements}

\subsection{Integration of appropriate landscaping measures}

Trees and all other natural vegetations are natural ways to keep the $\mathrm{CO}_{2}$ increase under check. They fix this $\mathrm{CO}_{2}$ during the day through photosynthesis while emitting $\mathrm{O}_{2}$ and maintain the crucial Carbon balance in the atmosphere. It is being assumed that a land area of 200 Sqm will be available in each of their premises for introducing landscape measures. These are proposed to be:

- Plantation of indigenous evergreen trees along front boundary

- Conservation of soil

- Plantation of Avicennia spp. - one of the most common mangrove species at peripheral areas.

Wackernagel and Rees [8] indicated that typical forest productivities of temperate, boreal and tropical forest show an accumulation of approximately 1.8 tonnes of carbon per hectare per year by an average forest. This works out to be $0.18 \mathrm{KgC} / \mathrm{m}^{2} /$ year. Assuming an average tree canopy to be $5.0 \mathrm{~m}$, each tree will occupy an area of $25 \mathrm{Sqm}$. This points to a $\mathrm{CO}_{2}$ sequestration amount of $(0.18 \mathrm{x}$ $25)=4.5 \mathrm{KgC} /$ year or $4500 \mathrm{gC} /$ year by each average tree. Therefore, 
undertaking a program of planting just 10 such trees will sequester $45 \mathrm{KgC} /$ year. Other than trees, soil under other natural vegetation or grass cover will also sequester Carbon to some extent. Related studies by Post and Kwon [9] have indicated $33.2 \mathrm{gC} / \mathrm{Sqm} /$ year fixation by soil. Considering an approximate 200 Sqm of earth area within the premises of this tourist facility, $(33.2 \times 200)$ or 6.64 $\mathrm{KgC} /$ year will be absorbed by these open spaces.

Considering the high Carbon fixing ability of Avicennia species (@5.475 $\mathrm{KgC/Sqm} /$ year), this thesis proposes its' planting on an area of $50 \mathrm{Sqm}$. This would help in fixing $(5.475 \times 50)=273.75 \mathrm{KgC} /$ year. It is obvious that $200 \mathrm{Sqm}$ of open area will remain covered by grass, ground covers and variety of flowering/ non-flowering shrubs. However, since no ready data was available on the rate of Carbon sequestration by other vegetations, this component has not been included in evaluating total $\mathrm{CO}_{2}$ sequestration possibility through landscaping measures.

Table 7 gives an account of the extent of $\mathrm{CO}_{2}$ negation by adopting landscape measures.

Table 7: $\quad$ Total carbon assimilation by landscape components.

\begin{tabular}{|c|c|c|c|c|}
\hline $\begin{array}{c}\text { Landscape } \\
\text { components }\end{array}$ & $\begin{array}{c}\text { A } \\
\text { Potential } \\
\text { Qtty }\end{array}$ & Unit & $\begin{array}{c}\text { C } \\
\text { Rate of C } \\
\text { sequestration }\end{array}$ & $\begin{array}{c}\text { (A x C)/ 1000 } \\
\text { Total Carbon } \\
\text { sequestration }\end{array}$ \\
\hline Trees & 10 & Nos. & 4500 & $\mathrm{ggC} / \mathrm{yr}$ \\
\hline Soil & 200 & $\mathrm{Sqm}$ & 33.2 & 45 \\
\hline Mangroves & 50 & $\mathrm{Sqm}$ & 5475 & 6.64 \\
\hline TOTAL & & & $\mathbf{3 2 5 . 3 9}$ \\
\hline
\end{tabular}

\section{Conclusions}

The retrofit possibilities against the three major resources of energy, water and landscape elements were explored in this paper and quantitative assessment for the first two were conducted to check the technical feasibility. The post-retrofit reduced foot-print of the lodge establishes the potentiality of sustainable retrofit measures into a strong possibility. About $90 \%$ of the total annual $\mathrm{CO}_{2}$ emission was found to be compensated by the energy retrofits, though the water retrofit situation was not very bright in annual terms. The verification of the post-retrofit environmental pay-back period for the lodge showed slow rate of pay-back. However, with improved efficiency in energy consumption like adopting energy efficient lamps and gadgets, and avoiding use of woody bio-mass as fuel, the post-retrofit annual emission will further come down. Therefore, the actual amount of $\mathrm{CO}_{2}$ negation would also increase resulting in a faster Environmental Pay-back period. It can, therefore, be stated that the building will become sustainable in the long run if the retrofits discussed here are adopted and adapted. 


\section{Acknowledgement}

The authors wish to thank All India Council for Technical Education (AICTE) for their support in carrying out this study.

\section{References}

[1] Blangy S. \& Mehta H., Ecotourism and Ecological Restoration, Journal for Nature Conservation, 14(3-4), pp. 233-236, 2006.

[2] IEEE Spectrum, Issue: February 2008, 45(2), Pg 56, 2008.

[3] Field Station Data, School of Energy Studies, Jadavpur University, 2004.

[4] Dias W.P.S. \& Pooliyadda S.P., Quality based energy contents and carbon coefficients for building materials: A systems approach, Energy, 29, pp. 561-580, 2004.

[5] Karmakar S, Study of Mangrove Biomass, Net Primary Production \& Species Distribution using Optical and Microwave Remote Sensing Data, M. Tech. Thesis, Andhra University, India, pp. 36 \& 40, 2006.

[6] West Bengal Pollution Control Board (WBPCB) website, www.wbpcb.gov.in

[7] Urban Development Plans Formulation and Implementation [UDPFI] Guidelines, Ministry of Urban Affairs \& Employment, Govt. of India, pp. 151-152, 1996.

[8] Wackernagel M. and Rees W., Our Ecological Footprint, New Society Publishers, 1996.

[9] Post W. M. and Kwon K.C., Soil Carbon Sequestration and Land-Use Change: Processes and Potential, Global Change Biology, 6, pp. 317-328, 2000. 